\title{
China and Deglobalization of the World Economy
}

Natasa Stanojevic ( $\square$ natasa.stanojevic@diplomacy.bg.ac.rs )

Institute of International Politics and Economics

\section{Katarina Zakic}

Institute of International Politics and Economics

\section{Research}

Keywords: deglobalization, China, protectionism, international trade, foreign investments, foreign value added, global value chains

Posted Date: June 16th, 2020

DOI: https://doi.org/10.21203/rs.3.rs-34425/v1

License: @ (i) This work is licensed under a Creative Commons Attribution 4.0 International License. Read Full License

Version of Record: A version of this preprint was published at National Accounting Review on March 21st, 2023. See the published version at https://doi.org/10.3934/NAR.2023005. 


\section{Abstract}

This paper analyses the causes of the downward trend in three key cohesion aspects of the world economy: international trade, foreign investment and global value chains. The paper finds that causes of these trends are not cyclical, but structural, that is, the process of deglobalization of the international market and transformation of the very foundations of the international economic system is underway. The specific aim of the paper is to investigate the impact of current trends on China's economy. The question is whether the Chinese economy, which has developed due to globalization processes, will be negatively affected by reverse processes and to what extent. The empirical analysis reveals very strong dependence of the Chinese economy on international economic trends. In spite of new development strategy which includes separation of the Chinese economy from disturbing external effects, most of current deglobalization trends have strong negative effects.

\section{Introduction}

Economic globalization defined as the process of integration of the international market of goods, labor and capital was the most significant development force in the second half of the 20th century. It evolved at three interdependent levels: international trade, international investment and international production. The intensification of these economic activities has produced different effects in different parts of the world, economic sectors and population groups, depending on the degree of involvement in international flows. The biggest winners of globalization are generally Asian countries. In addition to China, as the most successful economy in recent history, the positive effects of globalization are significant in South Korea, Singapore, Hong Kong, Thailand, the Philippines, Vietnam, Indonesia and India. Successful examples of Asian economies, along with intensive growth in foreign trade and foreign investment globally, have led to a rather overstated notion of the reach and nature of globalization. Contemporary globalization is considered as a spontaneous process of integration of a national into the world economy, as the only "right way", even historical inevitability and an irreversible process of civilization progress.

This paper argues that globalization is not an irreversible process, that modern globalization process has come to an end, and that the processes of deglobalization are leading to a significant transformation of the international economic order. The specific aim of the paper is to investigate the impact of deglobalization processes on the Chinese economy. Given that China's rise from poverty to the world's largest economy has been driven by globalization processes, the question is whether reverse processes will negatively affect the Chinese economy and to what extent.

The paper is divided into four chapters. The first chapter gives an overview of the literature that addresses a possibility of economic deglobalization, as well as the one exploring current trends of weakening global economic integration.

The second chapter analyses current declining trends in all key aspects of economic globalization: foreign trade, foreign direct investment (FDI) and global value chains (GVC). We have tried to answer the following questions: What are the causes of declining trends in globalization processes? Are they cyclical (transient) by nature? If not, is this a sign of deep structural changes in the world economy, which can be considered as an early stage of deglobalization process?

In the third chapter we analyze the shift in China's development strategy from "opening up" to "going out", which is aimed at protecting the Chinese economy from the disturbing effects of integration into the world economy. The effects of the new Chinese economic strategy on its international indicators will be explored. We are interested in whether some of these changes have contributed to deglobalization of the world economy.

The fourth chapter is an empirical analysis that aims to explore the effects of declining trends in global foreign trade, foreign direct investment and global value chains on the Chinese economy. This is a kind of test of the success of an altered Chinese development strategy.

\section{Literature Review}

The term deglobalization was first used by Walden Bello in the Deglobalization - Ideas for a New World Economy (2005). Bello does not consider deglobalization as an ongoing phenomenon, since the integration processes in 2005 were at their peak, but he proposes deglobalization as a process that would completely change the existing model of global economy governance.

Several authors consider a possibility that economic globalization is a transient process: Frankel (2000), James (2001, 2017), Baldwin and Martin (1999), Williamson (2002), Obstfeld and Taylor (2002), Sachs and Warner (1995), Taylor (1996). They put this phenomenon in historical perspective, by comparing it with the equally intense integration process of the world economy at the end of the 19th and the beginning of the 20th century. The similarity between the two waves (the term of Baldwin and Martin, 1999) of globalization is great both in political will and in economic indicators. Evidencing great similarities with the earlier process of globalization, the authors point to its transience and open the possibility that the process could be interrupted again as it happened in the 1930s.

Contemporary declining trends in the international economy have been explored by Constantinescu, Mattoo and Ruta (2015), Lewis and Monarch (2016) and Boz, Bussière and Marsilli (2015). These authors conclude that decline in international trade cannot generally be explained by cyclical economic factors. Although these studies do not consider changing the mainstream of the world economy, they are a significant starting point for this work, as they reliably eliminate many phenomena that could potentially lead to a temporary reduction in the volume of foreign trade.

Very few authors have analyzed broader context of current changes in the international economic system. Despite the undivided view on slowing down of the world economy integration, these authors have very different perceptions of the future direction of a change. Bordo (2017) notes widespread changes in the world economy: a decrease in the volume of foreign trade and foreign investment, withdrawal of GVC, an increase in regulation, but he concludes that it is a break in the process of global integration, not the end of the process. In contrast, Jacoby (2018) and Evenett (2019) analyze the current trend of mass trade protectionism, which they consider to be a symptom of serious disturbances in the international economic system and the beginning of deglobalization.

Page $2 / 11$ 
Ramo (2004) thinks that the nature of globalization is changing with China taking the leading position in the world economy. He defines the term Beijing consensus, as opposition to the once dominant Washington consensus. This concept has gained a significant number of supporters. Joshua (2019) believes that there is a "strategy shift occurring between the Washington Consensus and the Beijing Consensus" and Henderson, Appelbaum and Ho (2013) point to a new form of globalization, with "Chinese characteristics".

\section{Deglobalization Trends And Their Causes 3.1. International trade slowdown}

International trade was the most important aspect of global economic integration. Since the 1960s, the share of foreign trade in the world economy steadily increased until the Global Financial Crisis (GFC). With an average share of $24 \%$ in 1960 , it exceeded half of world GDP in early XX and reached a historic high of $61 \%$ in 2008 (World Bank). In 2009, GFC stopped the rapid growth of international trade. In the two years following the crisis, the volume of foreign trade was temporarily raised, but then further decreased, so that even a decade later, it has not reached the level from the previous period.

The current slowdown in foreign trade has a few specifics that indicate serious, structural changes in international trade. Previous periodic reductions in foreign trade were short-lived, usually one to three years. The current downtrend has been ongoing for a decade.

Further, the causes of the slowdown in trade are generally cyclical in nature, such as weakening of export economies or falling prices in the international export market. The current one cannot be explained by such cyclical factors, as indicated by the results of several empirical studies on the current trade slowdown. Constantinescu, Mattoo and Ruta (2015) find that only half of the decrease in international trade volume can be explained by the weakening of economic activity, that is, a decrease in GDP. Lewis and Monarch (2016) tested a possibility that the decline in trade volume was a reflection of a weakness in certain sectors of the world economy. Their model analyzed imports as a function of consumption, real exchange rates, and investment on the sample of several major economies. The results also show that the decline cannot generally be explained by the weakening of economies. The econometric model set by Boz, Bussière and Marsilli (2015) showed that common cyclical factors such as falling prices, declining demand and imports, all together make up less than a half of the sources of trade decline. The results of these three studies together capture all potential cyclical causes of international trade decline. They show that cyclical factors have a role to play, but neither individually nor collectively explain much of this trend.

A phenomenon that could explain a significant part of the process of weakening global trade is the sudden rise of protectionism, which is a third specific of the current trade trend. It particularly points to deeper changes in the world economy. Growing tendency to protect national economies from the environment rather than integrate into it reflects an important structural change in the international trade system. The weakening of economic activity during the GFC initiated a number of restrictive trade measures of developed and developing economies. A number of measures such as increasing tariffs, imposing quantitative restrictions and tightening customs rules escalated in the period 2008-2018. The World Trade Organization (WTO) states the following as a general feature of foreign trade: „During this period trade tensions continued to dominate the headlines and added to the uncertainty surrounding international trade and the world economy. The previous period saw a record level of new restrictive measures introduced" (WTO, 2019, p. 2). Import restrictions imposed between October 2017 and May 2019 covered over $\$ 800$ billion (WTO, 2019, p. 23). The coverage of new restrictive import measures introduced by the G20 economies during this period is three and a half times higher than in 2012, since the WTO calculates the coverage of trade restrictions (WTO, 2019, p. 2). According to the WTO, the total number of new trade-restrictive measures introduced in those seven months was 38. According to the Global Trade Alert (GTA), which includes trade remedies, the number of these measures is far greater. According to the GTA, the number of new restrictive measures is more than 1,000 each year or more than 2,000 measures in 2018.

The expansion of foreign trade restrictions began after the GFC. Several key trade routes have been suspended by a series of restrictive measures as early as 2012-2014. These are Russia's trade restrictions on the EU, North America and Latin America, then the sanctions imposed by the EU on Russia, in response to the annexation of Crimea. All of these restrictions are still in place.

The culmination of this trend was a trade war between the US and China, which marked the international trade in 2018 and 2019 . The new policy of US President Donald Trump meant strengthening domestic production by imposing extensive import restrictions. Tariffs for solar panels, washing machines, steel, and aluminum were among the first measures that cost the Chinese economy millions, although they also affected other exporters of these products to the US market. A series of import restrictions aimed directly against China followed. Responding to direct bans on Chinese goods, there was a Chinese restriction on imports of US goods. China has imposed high tariffs (15-25\%) on imports of US cars, aluminum, aircraft, pork, soybeans, fruits, etc.

The trade war of the two largest economies of the world has significantly affected the overall volume of international trade and contributed to a general loss of confidence in international institutions and liberal principles of the world economy. Yet, Trump's protectionist policies are merely a superficial reflection of a deeper and longer structural process of changing the direction of global integration.

At the end of 2019 , the countries most affected by the restrictions were China, with over 6,000 restrictions, Germany with more than 5,000 , followed by Italy, the USA, France, the United Kingdom, the Republic of Korea, Spain and the Netherlands with about 4,000 restrictive measures (GTA). Trade restrictions are one of the causes of the weakening of foreign trade, not only by direct losses, but rather the change of the entire trading environment in the world economy. The marginalization of international trade rules undermines the authority and role of the WTO, on which the global trade system is based. Passive role of international institutions in these cases, in some opinions, points to the need to reorganize the WTO. According to Jacoby (2018), a redesign of the International Monetary Fund (IMF), the World Bank, the G20, the WTO and "all other institutions responsible for monitoring trade and assuming the responsibility of actors" is necessary (Jacoby, 2018, p. 60). Evenett (2019, p. 15) points out that the WTO tends to mitigate the state of trade restrictions in its reports, by not including the mentioned trade remedies in harmful restrictions since 2017. The weakness and crisis of the WTO is particularly highlighted by the fact that the United Nations in 2019 adopted the Convention on International Settlement Agreements (Singapore Convention on Mediation), and thus 
established a parallel model for trade dispute settlement, which is already under the authority of the WTO. This UN act is probably not an act of deliberately devaluing the World Trade Organization, but a reflection of the real need to end concrete disputes.

\subsection{Reduction in foreign direct investment}

As in the case of international trade, the growth in foreign direct investment, uninterrupted over two decades, halved during the GFC. For the three years (20162019), the flows of international capital were decreasing sharper than international trade. FDI experienced the fastest growth in the 1990s, due to the opening of many new markets in the former Eastern Bloc. The FDI volume increased at a rate of over $20 \%$ per year (UNCTAD). Since the 2001 recession in developed economies due to the GFC, average FDI growth was $8 \%$, and in the period after the WFC, only $1 \%$. According to data presented in the annual UNCTAD reports for 2018 and 2019, FDI in some regions was at a record low. FDI decreased by $23 \%$ in 2017 and an additional $13 \%$ in 2018 , falling to less than $\$ 1300$ billion, which is the lowest level of FDI since the GFC.

Several early abrupt reductions in FDI, as in the case of trade, were the result of the economic recession in the European Union and the USA. The decline in economic activity in 2001 and 2007-2009 was cyclical, and, as expected, FDI quickly reached and exceeded the previous level after the emergence of large economies from the crisis. The current decline in foreign investment is not the result of any crisis. Economic growth has slowed globally, but it is still growth, and no major economy is in recession. Thus, deeper causes of FDI fall must also be sought, and the starting point is to determine the origin of FDI that is largely adding to the downward trend. Developed countries have a huge share in the total FDI inflow, so changes in investment flows in developed countries show almost identical changes as in global flows. The inward FDI in developed countries have fallen by 27\% in 2018 (UNCTAD, 2019a, p. 2) and dropped to the level of 15 years ago. The inflow of FDI into Europe is halved, with some countries registering a negative inflow as a result of the withdrawal of investment funds by US multinational companies (MNC). Outward investment from developed countries, with a $40 \%$ decline in 2018 , plays a key role in the overall FDI outflow decline. Their share in total investment dropped to 55\%, the lowest share ever recorded (UNCTAD, 2019a, pp. 2-3). Investment originating in developing countries has also been reduced, but to a much lesser extent, by $10 \%$. These data shall be used later for explaining China's role in global capital flows.

Temporary return of capital to foreign markets in the aftermath of the GFC indicates that there were still profitable opportunities, and secondly, that foreign investors partly regained confidence in the stability of the world economy, or at least in the stability of the economies of the countries where they invested. The decline that followed indicates that at least one of these incentives for attracting FDI has changed.

After several decades of intensive capital investments, the global financial market reached saturation. Profitable opportunities for new investments were simply exhausted. In addition, due to the "law of convergence", the openness and connectivity of globalized economies led to equalization of labor prices and production conditions in developed and developing countries. Globalization itself has provided rise of labor prices in the most attractive destinations of foreign capital - the countries of East and Southeast Asia, thereby depriving them of a key aspect of attraction for FDI. Both of these phenomena are "natural" limitations of globalization, but both are of relatively lasting character.

Trust in investment security, as another important condition for FDI, is severely disrupted by restrictive policies of large economies. The number and scope of restrictive measures in the area of foreign investment have a pronounced upward trend since the WFC. Restrictive measures include a number of instruments, which have negative effects on FDI in different ways. The most direct measures concern the restriction or prohibition of the inflow of foreign investment in certain economic sectors, but there are also restrictions on outward investment in certain foreign countries or sectors. The states that are home of the largest MNC are intensifying their efforts to reduce and discourage capital outflows. Such measures have been adopted by the Committee on Foreign Investment of the USA, the European Commission, Germany, the United Kingdom, Italy, as well as China.

The total number of restrictive foreign investment measures introduced in 2018 alone is 418 (GTA). According to UNCTAD (2019), the share of restrictive measures in total measures related to FDI increased from $10 \%$ to $34 \%$ in $2003-2018$, that is, measures contributing to FDI liberalization were reduced from $90 \%$ to $66 \%$. This is the largest restriction share since 2003. In addition, in 2018,22 business projects that had been started with foreign capital were blocked, which is twice as high as in 2017 (Hanemann and Lysenko, 2019, p. 15).

FDI are generally considered positive for the economy of a host country, so restrictions in this volume are unexpected. Investment restraints are common in national security sectors and often in the energy sector. However, since the WFC the number of protected sectors has increased encompassing some of the most profitable services and products. Most new measures relate to investment restrictions in the fields of telecommunications, the Internet, production of electrical components (semiconductors, diodes, and transistors), robotics, artificial intelligence, IT systems used in key industries, etc. (UNCTAD, 2019b).

Particularly frequent is the introduction of screening, mandatory assessment of the inflow of foreign investment by an authorized agency. This mechanism was introduced by 24 countries, which together account for more than a half of the world's cumulative FDI. Also, more than 40 amendments to the list of sectors or economic activities subject to screening were adopted in the 2018 and 2019.

Direct impact of new restrictions on the total volume of FDI cannot be quantified. They are, to a certain extent, a direct cause of the decline in FDI, but more importantly they create unfavorable investment climate, which in the coming period will contribute to further disinvestment.

\subsection{Deconstruction of global value chains}

One of the key aspects of modern globalization is the international segmentation of production processes. The goal and driver of international production segmentation was to achieve the most cost-effective structure for each stage of the production process. This is the core activity of modern MNC. Almost all exporting companies, with or without the participation of foreign capital, are parts of global value chains (GVC), also called production chains or supply

Page $4 / 11$ 
chains. In its broadest form, globalized production is seen as a global production network, grouping of interconnected but geographically dispersed production units. Global production networks have become a dominant feature of the modern world economy. One third of total international trade takes place between global corporations and another third within their GVC, meaning that most global exchanges take place within global manufacturing networks.

The flow of inputs within GVC cannot be measured by even the most accurate foreign trade data for a given group of products between countries involved in its production. Namely, statistics always show the final value of an exported product, not considering that the value of import of components for that product is only slightly lower (for added value) than the value of the exported product (Stanojević, Kotlica, 2018, p. 26). For more complex final products, it is not uncommon for a product to cross several borders or the same border several times at different stages of production. Trade statistics, at each transit, record the entire value of the product. External trade data have thus become over-dimensioned. Instead of this data, the indicator of economic integration in international production is foreign value added (FVA). Foreign value added is the value of an imported semi-finished product that is ready for further processing and export. This data is collected by the OECD (Trade in Value Added Database - TiVA), WIOD (World Input-Output Database) and UNCTAD (Eora Global Value Chain Database) using partially different methods. In this analysis, we have used UNCTAD data as it relates to the most recent period.

From 1990 to 2010, the rise of share of FVA in exports was gradual - 7 percentage points in 20 years, but steady, without interruptions (UNCTAD, 2018, p. 22). FVA, like most economic indicators, fell sharply in 2008 and 2009 due to the WFC. As in the case of foreign trade and investment, there was a temporary, moderate recovery of FVA, and then, for no apparent reason, it has been declining since 2015 in a large number of countries. FVA was globally reduced in 10 years from $31 \%$ in 2008 to $27 \%$ in 2018 . UNCTAD (2019b, p. 2) estimates that stagnation or a slight decline will continue in the coming years.

The host countries of the largest multinational companies, the US and the UK, are also facing a steady decline in FVA, as does Germany, whose international production is mainly taking place in the European Union's neighborhood, with negligible share in Asian markets. In the years after GFC, FVA share in US exports decreased from 12 to $9.5 \%$, in the UK from $33 \%$ to $26 \%$, in Germany from $52 \%$ to $43 \%$, in France from $38 \%$ to $33 \%$ (author's calculation).

The shortening of GVC was caused by the same causes as the decline in trade and FDI. Multinational companies are retreating into national contexts partly because of the global market volatility, caused by the GFC, and partly due to the mentioned changed conditions, which no longer provide extreme profits. With the convergence of international input prices, too long GVC no longer justifies high transportation costs. Extraterritorial production may still have justification in lower taxes or geographic proximity to the market, as classical motives, but global value chains have actually become regional value chains.

\section{New China Development Strategy And Deglobalization}

China's policy of "opening up" during the 1980s and 1990s related to opening the country for inflow of foreign capital into China, as well as exporting Chinese products. The success of this reform has provided China with huge capital surpluses. Chinese government decided to use it for promotion of Chinese investments abroad, and initiated a new "going out" policy at the beginning of 2000s. An important segment of the new strategy was focused on changing China's position as a major capital importer, to one of the largest international investors. New large-scale Chinese investments were placed across Africa and Latin America in the next period. Relying on exports and expanding export markets remained a part of this development strategy.

The GFC hit the Chinese economy significantly in 2008 and 2009, pointing to its fragile position of dependence on international economic flows. This considerably accelerated the implementation of and extended a new Chinese strategy. Changing China's development strategy marked the beginning, but in part, the cause of the deglobalization of the world economy. The difference with "going out" strategy is abandoning exports as a primary growth driver and focusing on domestic demand. Rapid trade growth over the two and a half decades peaked at $63 \%$ of Chinese GDP in 2006 . Because of the change in export orientation the share of foreign trade in GDP started to decline already in 2007, and it sharply fell to $33 \%$ in 2018 (Figure 1).

Relatively protected middle-income domestic market of 1.36 billion inhabitants enables China to have, though no more spectacular, but steady economic growth. When it comes to foreign investment, the Chinese economy made similar changes. The largest share of FDI net inflow in Chinese GDP was 5-6\% in the mid-1990s. In the early 2000s it was about 3\%, and after 2013, barely exceeded $1 \%$ of GDP (Figure 2). This was a Chinese step towards deglobalization.

In contrast, FDI outflow was 1\% of GDP in 2008 and maximum share of $1.8 \%$ was reached in 2016 . From 2013 to 2016 , China invested hundreds of billions of dollars in overseas infrastructure projects under the Belt and Road Initiative (BRI). China has kept investing abroad as a direction of development, mapped out in the "going out" strategy. In the current development strategy, outward FDI has more significant place. BRI may be seen as a concrete extension of previous Chinese policies (Joshua, 2019, p. 42).

However, for two consecutive years, in 2017 and 2018, China faced a decline in investment. In particular, the volume of Chinese investment in the US diminished from $\$ 46$ billion in 2016 to $\$ 29$ billion in 2017, then to $\$ 4.8$ billion in 2018, or 90\% in two years (Hanemann and Lysenko, 2019). Some of the investments in America were sold because of the uncertainty and disruption in economic relations between the two countries. Chinese investment in other countries was also reduced, mainly due to significantly reduced reserves, numerous inefficient investments and failure to collect claims from debtor countries. The share of FDI outflow dropped to pre-BRI levels at about $1 \%$ of GDP.

From the point of view of the third aspect of globalization, i.e. integration in GVC, China has also been strengthening its independence since 2000. Participation in GVC in the early stages allowed China to set up production facilities with foreign capital, thus laying the foundation for its industry. On the other hand, it generated greater profits for those 'lead firms' in the value chain that control branding and product conception (e.g., Apple). At the same time, contract manufacturers (e.g., call centers) „tend to earn slim profits and may never develop the autonomy or capabilities needed to develop and market their own branded products. Typically, firms that provide routine assembly tasks and other simple services within GVC earn less, pay their workers less, and are more vulnerable to business cycles..." (Gereffi, 2018, p. 367). 
China is abandoning this position quickly and successfully. In Chinese exports, the share of imported components is continuously decreasing and the share of domestic components is increasing. According to UNCTAD data on foreign value added, and the World Bank's total exports, we have determined the degree of integration of the Chinese economy into global product chains. The share of foreign value added in exports has abruptly declined since 2000 (Figure 3 ). This change was brought about by the economic rise of China itself, which over the two decades has significantly altered the condition, structure and potential of the Chinese economy.

The decrease in FVA, and thus the share of global product chains, is the result of technology development. Initially, Chinese manufacturing and exports were dominated by products with low domestic value added, usually performing the final assembly of products using imported components. The development of Chinese production was based on the shift towards exporting goods with a greater share of domestic value added. Over time, China expanded from assembly activities to the "production of lower-technology peripheral products, such as computer keyboards, and then to an increasing number of parts and components" (Jenkins, 2019, p. 47). The study of Kee and Tang (2016) finds that the substitution of domestic for imported materials was induced by greater variety of domestic materials becoming available at lower prices. Reducing the share of FVA in Chinese exports (upstream links) means a climb in global manufacturing networks. Instead of positioning itself as one of many manufacturers in one of numerous manufacturing phases of vertical manufacturing, China is heading towards the center of the manufacturing network by taking over larger and larger parts of the production chains.

For China gaining partial independence from other participants in the production process means shortening of production chains, that is, another step towards deglobalization. On the other side of vertical production, i.e. downstream links, the volume of Chinese exports incorporated into other products abroad and then re-exported is continually increasing (Jankins, p. 47). This also reduces the number of participants, especially other developing countries, in the product chains in which China is included.

Finally, by taking over the entire manufacturing process, especially when it is supported by its own innovations and brands, China is on the way of transforming from the world's workshop into a world manufacturing power. The once-cheap labor force, as the main motive for the presence of MNC from all developed countries and the driver of international production, has risen to a level of median income. The production without any environmental and labor regulations is also the matter of the past. China is gradually squeezing large MNC out of production chains, but, the rise of China within global product networks is a long-term process, which has recently begun. Several of the world's largest companies (Apple, Adidas, Samsung, Philips, etc.) are still operating in China, bringing their brand, market, techniques and technologies, and taking all the profits. In this sense, China's economy is far from central position in international manufacturing and from resilience to changes in international manufacturing.

Thus, the Chinese economy, as well as developed countries, is reducing the degree of its integration into the world economy in all aspects: foreign trade, FDI inflow and outflow and GVC. This is generally not a failure of the Chinese economy, but the result of a revised development strategy and conscious efforts of the Chinese government to transfer the key economic backbone to the domestic market, so that economic success does not depend on external shocks. The question is whether this Chinese strategy has been successful or deglobalization trends have weakened China's economy. The aim of the empirical research that follows is to determine the extent and direction of this influence.

\section{The Impact Of Deglobalization On The Chinese Economy 5.1. Variables and methodology}

The impact of previous analysis of deglobalization trends: international trade, investment, and international production, on China economy will be empirically analyzed. Three independent variables are observed at the global level $(w)$ and dependent variable is China economy $(c)$ in a selected year $(t)$.

$$
G D P_{c t}=\mathrm{f}\left(T R A D E_{w t}, I N V_{w t}, P R O D U C T_{w t}\right)
$$

General multiple regression model has a following form:

$$
Y_{i}=\beta_{0}+\beta_{1} X_{1}+\beta_{2} X_{2}+\ldots+\beta_{\mathrm{n}} X_{n}+e_{i}
$$

where: $Y i$ is dependent variable, $\beta_{0}$ is $\mathrm{Y}$-intercept, $\beta$ is $(\mathrm{i}=1,2 \ldots \mathrm{n})$ are the regression coefficients, $x_{1}, x_{2}, \ldots, x_{\mathrm{n}}$ are independent or explanatory variables, and $e_{l}$ is the models` error term or residuals.

As stated in the previous chapter, what indicates a tendency towards deglobalization of the world economy is a continuous and significant decrease in the share of three main indicators in the world economy, i.e. a decrease in their importance. The model variables are defined as the share of global trade and FDI in global GDP, and the share of FVA in global Export instead of their values. All variables are in logs.

Thus, the model takes the following form:

$$
\ln Y_{c t}=\beta_{0}+\beta_{1} \ln T_{w t}+\beta_{2} \ln F D I_{w t}+\beta_{3} \ln F V A_{w t}+e_{i}
$$

where $Y_{c t}$ is GDP of China in current US\$ in year $t, T_{w t}$ is the world trade (export +import) as a share of global GDP in year $t, F D I_{w t}$ is world FDI net inflow as a share of global GDP in year $t, F V A_{w t}$ is foreign value added as a share of world export in year $t,{ }_{w}$ denotes world data.

Since that FDI net inflow includes both inflow and outflow, it is possible that they have opposite effects on China economy. To test this, we have created another model where the global FDI variable is decomposed into inflow and outflow FDI, instead of FDI net inflow as a common indicator. 
$\ln Y_{c t}=\beta_{0}+\beta_{1} \ln T_{w t}+\beta_{2} \ln / N F_{w t}+\beta_{3} \ln O U T_{w t}+\ln \beta_{4} \ln F V A_{w t}+e_{i}$

The empirical analysis is based on an Ordinary Least Squares (OLS) regression which is used for estimations of parameters of linear equations. The parameters of the equations were defined by minimizing the residual sum of squares. The model uses time series data for the period $1990-2018$. Source of data for GDP, share FDI in GDP and share of trade in GDP is the World Bank indicator database. UNCTADstat provides the data on the value of inflow and outflow FDI, and FVA statistics is taken from the UNCTAD Eora database.

\subsection{Multicollinearity}

The independent variables which will be used for measuring the degree of globalization (deglobalization) are highly linearly related. Correlations between the predictor variables are $0.65,0.81$ and 0.88 (table 1 ).

Table 1. Correlations between the predictor variables

\begin{tabular}{lccr}
\hline & $\begin{array}{c}\text { Trade } \\
(\% G D P)\end{array}$ & $\begin{array}{c}\text { FVA } \\
\text { (\%Export) }\end{array}$ & FDI net inflows (\%GDP) \\
\hline Trade (\%GDP) & & 0.8822 & 0.8131 \\
\hline FVA (\% Export) & 0.8822 & & 0.6510 \\
\hline FDI net inflows (\% GDP) & 0.8131 & 0.6510 & \\
\hline
\end{tabular}

Source: Author's calculation

Multicollinearity exists whenever an independent variable is highly correlated with one or more of the other independent variables. Multicollinearity is most often a problem because it generates a relatively large standard error and the large standard error of a regression coefficient undermines the statistical significance of an independent variable. However, multicollinearity "caused by the inclusion of powers or products of other variables" is one of the three cases when this phenomenon does not affect the model's predictive accuracy. This "is not something to be concerned about, because the p-value is not affected" (Allison, 2012).

This is the case with the model's variables. Multicollinearity is quite expected given that the selected variables are just segments of one and the same phenomenon of the contemporary world economy - global value chains. FVA is a part of foreign trade, and it is also very often the result of FDI within GVCs, just like the exports. This allows us to ignore multicollinearity, which should be confirmed by the statistical significance ( $p$-value) of the variables and low standard error.

In addition, multicollinearity does not introduce bias. "It is not an econometric problem in the sense that it would violate assumptions necessary for regression models to work" (Lindner, Puck, Verbeke, 2019, p. 283).

\subsection{Results and discussion}

The results obtained can be considered statistically reliable and valid by all criteria. Coefficient of determination $\mathrm{R}^{2}$ and adjusted $\mathrm{R}^{2}$ in both models are very high, 0.92 to 0.95 (table 2). This indicates that more than $92 \%$ of variation in China GDP can be explained by the variation in the selected global indicators. $P$ statistics shows that all variables are significant, i.e. $p$ values are lower than 0.01 for all variables except $F D I$, with $p$ value lower than 0.05 in the first model, and lower than 0.01 for all the variables in the second model. This indicates extreme sensitivity of the Chinese economy to changes in the share of international trade, investment and production in the world economy.

Table 2. Regression analysis results 


\begin{tabular}{lrr}
\hline Variable & \multicolumn{1}{c}{$(1)$} & \multicolumn{1}{c}{$(2)$} \\
\hline Intercept & $-23.9571^{* *}$ & $-18.9726^{* *}$ \\
& $(2.8077)$ & $(2.1291)$ \\
$\ln T$ & $5.8113^{* *}$ & $3.9597^{* *}$ \\
& $(1.1945)$ & $(0.9692)$ \\
$\ln F D I$ & $-0.4946 *$ & \\
& $(0.1930)$ & \\
InFVA & $4.7849 * *$ & $5.4289^{* *}$ \\
& $(1.3102)$ & $(0.4709)$ \\
lnINF & & $1.4937 * *$ \\
& & $(0.4930)$ \\
lnOUT & & $-1.9299^{* *}$ \\
\hline R Square & & $(1.1574)$ \\
Adjusted R Square & 0.9196 & 0.9379 \\
Standard Error & 0.3389 & 0.2978 \\
F & 107.7969 & 106.8245 \\
Significance $F$ & & \\
+ & 0.0000 & 0.0000 \\
\hline
\end{tabular}

Notes: ** and * represent significance at 1 and 5 percent, respectively. Standard Error is given in parentheses.

Multicollinearity, as expected, has not negatively affected the p-value, nor has it generated a high standard error. However, due to the choice of these variables, the model cannot accurately assess their particular impacts on a decrease in China's economy. This is not a problem because the aim of the research was not to determine the effects of the individual aspects of the international economy on the Chinese economy, but rather their synergy effects.

What the model shows with high certainty is that China's economy is under extremely strong influence of global trade openness, ramifications of global value chains and FDI volumes. This is indicated by the very high determination coefficients of $91 \%$ and $93 \%$, as well as statistical significance higher than $95 \%$ and $99 \%$ for all the variables in both models.

The resilience of the Chinese economy to the global capital flows shown by the first model is partly due to the fact that the largest FDI inflow was during the 1980s and 1990s, when the first large MNC began production in China. The result of the first model shows the absence of the influence of the current declining trend, not the absence of the influence of foreign capital already placed in China. As the impact of the global FDI net inflow variable is measured, the model also does not include the effects of strengthening China's position as a global investor, of which China derives numerous economic benefits.

In the second model, as it is expected, the impacts of inflows and outflows of global FDI have proven to be opposite. Coefficient for the FDI outflow variable has inverse impact, indicating the growth of the share of global FDI outflows in the world GDP leads to a decline in China's GDP. In contrast, the increase in global FDI inflow has a positive impact on the Chinese economy.

\section{Conclusion}

The trends that marked the globalization of economies at the end of the XX and the beginning of the XXI century took the opposite direction after the World Financial Crisis. The world economy, which has operated for several decades on the basis of internationally accepted rules, is returning to the framework of bilateral interactions of economic entities - companies and countries. Trade, investment and production are affected by intensive processes of withdrawal from the international to the national level. The recent restrictions on international interactions due to the pandemic of Covid19 have greatly accelerated these processes. Coronavirus has particularly disrupted global value chains. After the pandemic, many international trade flows will not be resumed, as each country will find domestic resources or geographically close partners for the most important imported products.

Some causes of deglobalization processes, such as global market saturation and the international convergence of labor prices, have foundation in economic laws. In addition, in each of the analyzed segments, there is one thing in common, and that is the political will of the key players, expressed by the growing protectionism in the field of international trade and foreign investment. Both groups of causes of deglobalization are relatively long-term by nature, they do not have cyclic character, therefore will not be significantly changed in accordance with the changes in indicators such as economic growth, supply, demand, productivity etc. On this basis, we conclude that deglobalization is a relatively lasting, fundamental process that transforms the entire international economic system.

Significant changes in Chinese development strategies aimed at protecting domestic economy from external shocks, have led to a decrease in the share of all international indicators in the Chinese economy. So, China is also contributing to the deglobalization of the world economy, although the impact of its new development strategy is far weaker than that of strong protectionism in developed countries.

A quantitative analysis of the opposite impact, e.g. of deglobalization on the Chinese economy showed that international economic integration have a strong impact on China's economy. This means that current downtrend in the economic globalization will negatively affect the Chinese economy.

Page $8 / 11$ 
The new Chinese development strategy, which is oriented towards domestic production to meet domestic demand, financed by internal resources, is still not strong enough to separate the development of the Chinese economy from global trends.

In the segments of international trade and international production, deglobalization processes have strong negative effects on China seconomy. The $\neq$ wstrategyofrely $\in$ gondomesticmarkethas $\neg$ reducedtheCh $\in$ eseeconomy'srelianceon $\exp$ or $t s \rightarrow$ therequired $\leq$ s successful takeover of growing parts of global product chains. Namely, that has reduced dependence of China's production on FVA, but Chinese products and parts are included in almost all production chains across the world. On the global level, a decrease in FVA means a decrease in imports of Chinese inputs in foreign production, which directly harms the Chinese economy. From the perspective of global production networks, China's dependence on international production is as great as the dependence of global production on China's economy.

Although China's economy is still heavily dependent on the global economy, it has a strong influence on the world economy integration through its massive investment within the Belt and Road Initiative. Representing and applying the so-called win-win approach, which implies mutual benefits of partners and realization of long-term interests in a particular country or region, China offers investment with more favorable effects than foreign direct investment in general. By gradually approaching the countries involved in the BRI, China is gaining increasing geopolitical influence. Belt and Road Initiative today is the most dynamic and unique segment of the globalization process. It may not have as much potential to maintain the previous intensity of economic globalization, but it does give it a new shape and character.

\section{Declarations}

\section{Availability of data and materials}

The datasets analysed during this study:

Source of data for GDP, share FDI in GDP and share of trade in GDP is the World Bank indicator database available from: https://data.worldbank.org/indicator.

UNCTADstat provides the data on the value of inflow and outflow FDI, and FVA statistics is taken from the UNCTAD Eora database available from:

https://worldmrio.com/unctadgvc

\section{Funding}

No funding is used for this study.

\section{Author information}

\section{Affiliation}

Institute of International Politics and Economics, Belgrade, Serbia

NatasaStanojevic

Institute of International Politics and Economics, Belgrade, Serbia

Katarina Zakic

\section{ponding author}

Correspondence to:NatasaStanojevic

\section{Ethics declarations}

\section{Competing interests}

There is no competing of interest.

\section{Author contribution}

NS explored the deglobalization trends in the world economy and made a quantitative analysis of its impact on Chinas` economy. KZ explored the details of New China Development Strategy and analyzed the current trends in foreign trade, FDIs and GVCs of China. Both authors read and approved the final manuscript.

\section{References}

Allison P (2012) When Can You Safely Ignore Multicollinearity? Statistical horizons https://statisticalhorizons.com/multicollinearity. Accessed 21 April 2020.

Baldwin R, Martin P (1999) Two waves of globalization: Superficial similarities, fundamental differences. NBER Working Paper 6904.

Bello W (2005) Deglobalization - Ideas for a New World Economy. London and New York: Zed Books Ltd. 
Bordo M (2017) The Second Era of Globalization is Not Yet Over: An Historical Perspective. NBER Working paper 23786.

Boz E, Bussière M, Marsilli C (2015) Recent slowdown in global trade: Cyclical or structural? in Hoekman B (ed.) The Global Trade Slowdown: A New Normal? London: Centre for Economic Policy Research.

Constantinescu C, Matoo A, Ruta M (2015) Global Trade Slowdown in Hoekman B (ed.) The Global Trade Slowdown: A New Normal? London: Centre for Economic Policy Research.

Evenett S (2019) Protectionism, state discrimination, and international business since the onset of the Global Financial Crisis. Journal of International Business Policy, 2(1): 9-36.

Frankel J (2000) Globalization of the economy. NBER Working paper 7858.

Gereffi G (2018) Global Value Chains and Development - Redefining the Contours of 21st Century Capitalism. Cambridge: Cambridge University Press.

Henderson J, Appelbaum RP, Ying Ho S (2013) Globalization with Chinese Characteristics: Externalization, Dynamics and Transformations. Development and Change 44 (6): 1221-1253.

Jacoby D (2018) Trump, Trade, and the End of Globalization. Santa Barbara and Denver: Praeger.

James H (2001) The End of Globalization - Lessons from the Great Depression. Cambridge: Harvard University Press.

James H (2017) Deglobalization as a Global Challenge. CIGI Papers 135.

Jenkins R (2019) How China Is Reshaping the Global Economy: Development Impacts in Africa and Latin America. Oxford: Oxford University Press.

Joshua J (2019) The Belt and Road Initiative and the Global Economy - Trade and Economic Development. Cham: Palgrave Macmillan.

Kee, HL, Tang H (2016) Domestic value added in exports: Theory and firm evidence from China. American Economic Review 106 (6), $1402-1436$.

Lewis L, Monarch R (2016) Causes of the Global Trade Slowdown. International Finance Discussion Paper Notes 2016-11-10. Washington: Board of Governors of the Federal Reserve System.

Lindner T, Puck J, Verbeke A (2019) Misconceptions about multicollinearity in international business research: Identification, consequences, and remedies. Journal of International Business Studies 51, 283-298.

Obstfeld M, Taylor A (2002) Globalization and Capital Markets. In Bordo M, Taylor A, Williamson J (eds.) Globalization in Historical Perspective. Chicago: University of Chicago Press.

OECD. TiVA database, (2018). https://www.oecd.org/industry/ind/measuring-trade-in-value-added.htm\#country-notes. Accessed 9 March 2020.

Ramo JC (2004) The Beijing Consensus: Notes on the New Physics of Chinese Power, London: Foreign Policy Centre.

Hanemann T, Gao C, Lysenko A (2019) Net negative: Chinese Investment in the US 2018. Rhodium group. https://rhg.com/research/chinese-investment-in-theus-2018. Accessed 11 March 2020.

Sachs J, Warner A (1995) Economic reform and the process of global integration. Brookings Papers on Economic Activity, 1, 1-118. Washington: Brookings Institution.

Stanojevic N, Kotlica S (2018) Globalization and Methodology of Researches in International Trade. Industrija, 2(46), 21-38.

Taylor A (1996) International capital mobility in history: the savings-investment relationship. NBER Working Paper 5743.

UNCTAD, Eora Global Value Chain database (2018) https://worldmrio.com/unctadgvc Accessed 2 March 2020.

UNCTAD (2018) World Investment Report - Investment and New Industrial Policies. New York: United Nations.

UNCTAD (2019a) World Investment Report - Special Economic Zones. New York: United Nations.

UNCTAD (2019b) Global investment trend monitor 32. New York: United Nations.

UNCTADstat database (2019) https://unctadstat.unctad.org/EN/ Accessed 18 March 2020.

United Nation (2019) United Nations Convention on International Settlement Agreements Resulting from Mediation. New York: United Nations.

\section{Figures}




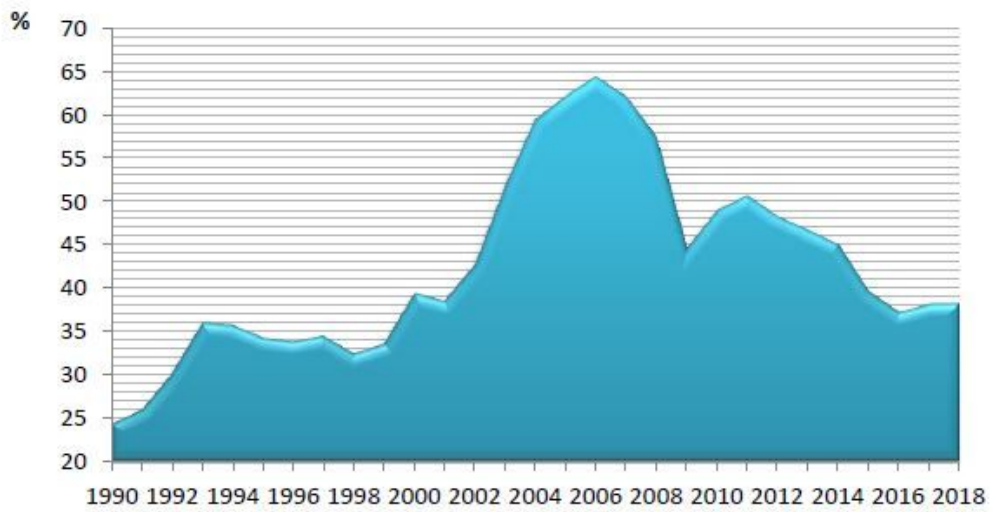

Source: World Bank indicators

\section{Figure 1}

Share of foreign trade in the GDP of China

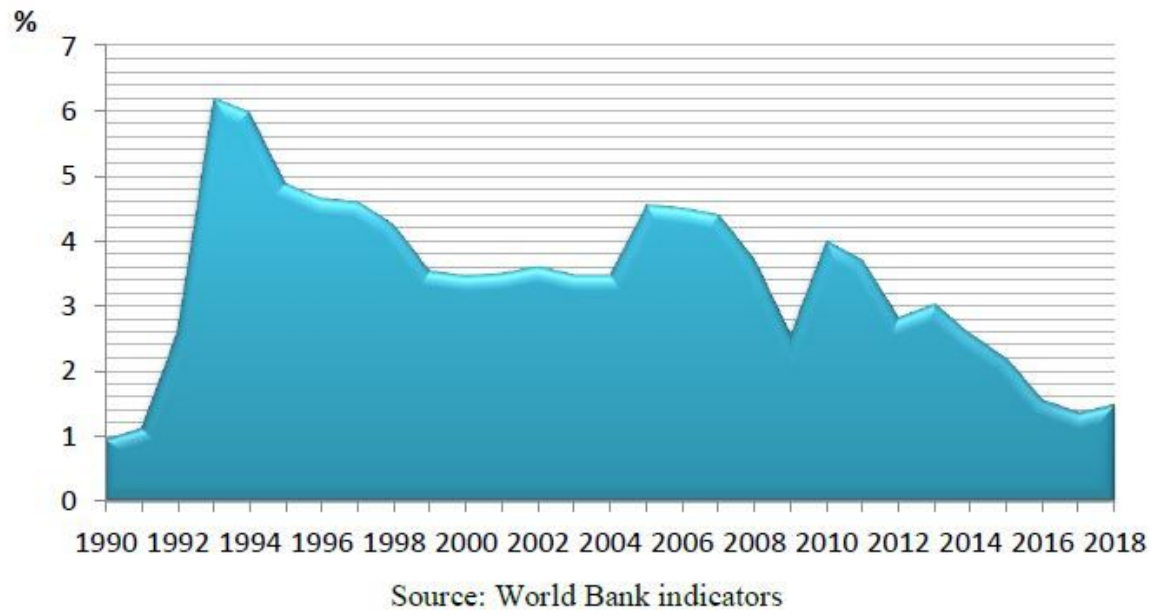

Figure 2

Share of FDI in the GDP of China

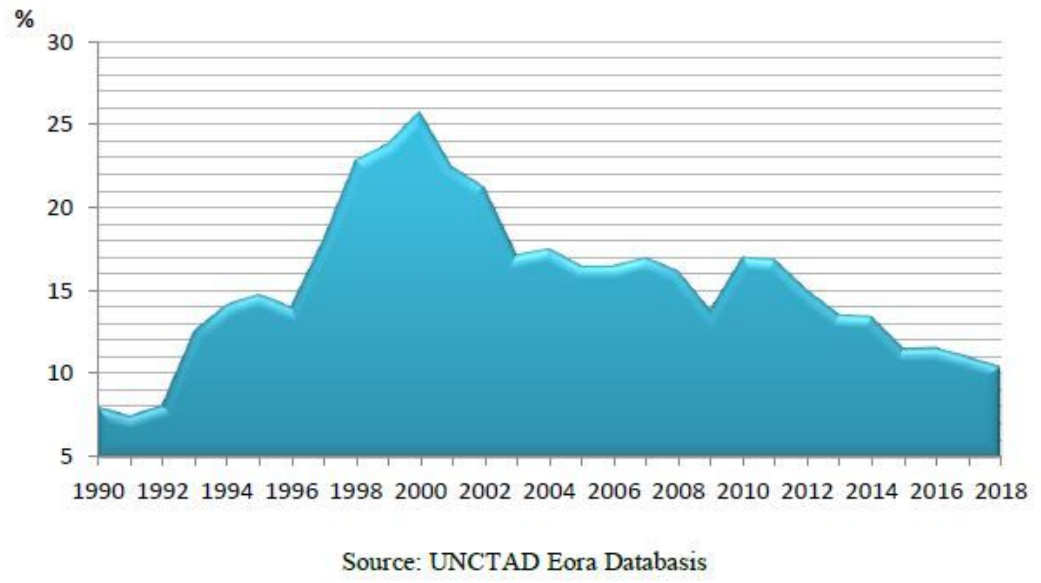

Figure 3

Foreign value added in China's export 